Gillespie, S. (2020) Imitating the obscene: Henry Higden's versions of Horace's Satire 1.2 and Juvenal's Satire 6. Translation and Literature, 29(2), pp. 199-219.

(doi: $\underline{10.3366 / \text { tal.2020.0418) }}$

There may be differences between this version and the published version. You are advised to consult the publisher's version if you wish to cite from it.

\title{
http://eprints.gla.ac.uk/209883/
}

Deposited on 12 February 2020

Enlighten - Research publications by members of the University of Glasgow http://eprints.gla.ac.uk 


\section{Imitating the Obscene: Henry Higden's Versions \\ of Horace's Satire 1.2 and Juvenal's Satire 6 \\ Stuart Gillespie}

Henry Higden (bap. 1645), a product of Westminster School, entered the Middle Temple in 1665. He was not called to the bar until 1686, the same year in which the first of his three published works appeared. This was a translation or imitation of Juvenal's Satire 13 titled A Modern Essay on the Thirteenth Satyr of Juvenal, published by Dryden's bookseller, the young Jacob Tonson. When his next production, a version of Juvenal's Satire 10, appeared in 1687 as A Modern Essay on the Tenth Satyr of Juvenal, it was prefaced by commendatory verses from Dryden, with similar contributions from Aphra Behn and Elkanah Settle.

Charles Gildon described his contemporary Higden as 'a Person known to all the conversable part of the Town, for his Pleasant and Facetious Company'. ${ }^{1}$ His social prominence may help explain his sorry legal career: he is reported by Tom Brown as being forced to take measures to prevent his room in the Temple being padlocked for non-payment of rent. ${ }^{2}$ Neither did his success as a writer prove enduring. Higden's sole attempt at a stage play ended in disaster in 1693, when his comedy The Wary Widow was badly cut (by the Master of the Revels), badly produced, badly performed, and badly received. No further plays or other publications appear to have followed, and by the time Gildon recorded his biographical notes on Higden in 1699, he could not say whether he was still alive. His later fate is unknown.

Higden's two published classical imitations have, however, had their admirers. Dryden not only commended his Modern Essay on the Tenth Satire of Juvenal in his dedicatory verses, but

\footnotetext{
${ }^{1}$ Gerald Langbaine, continued by Charles Gildon, The Lives and Characters of the English Dramatick Poets (London, 1699), p. 72.

${ }^{2}$ The Second Volume of the Works of Mr Thomas Brown (London, 1715), p. 177.
} 
borrowed details from it extensively when he composed his own more celebrated version of the satire a few years later in 1693. The relationship between the two works has been explored in these pages by David Hopkins, who concluded that Dryden's debt to Higden implied very close knowledge of his version, and that Dryden was able to develop and improve on many of Higden's hints. Hopkins characterizes Higden's work as ‘sometimes uncertain', his octosyllabic verse often producing a 'trivializing' effect at odds with the 'lapidary dignity' he attains at his best.

Nevertheless, Higden, Hopkins shows, suggested to Dryden how wit and moral sententiousness could be 'viably combined'. 3

As a translation, Higden's version of Juvenal 13, also in rhyming octosyllabic couplets, takes the same free approach its writer defended in the Preface to his Juvenal 10, which declares his aim of giving 'Life and Spirit to his Author, by making him English, in a Modish and Familiar way'. It too feels at times like burlesque, not least in the balancing act its versification involves:

Both Law and Equity afford

A Thousand Precedents on Record;

Demonstrating, That Breach of Trust is

So frequent, 'tis scarce thought Injustice. ${ }^{5}$

Octosyllabic couplets are a rare verse form indeed in imitations of ancient satire (as in imitations of other ancient genres) in the later seventeenth century. In her commendatory verses for Higden's Juvenal, Aphra Behn anticipates that some readers will 'blame' his 'Measures', given that Juvenal 'drest his Satyr in more lofty Rhimes'. But, she reassures him,

\footnotetext{
${ }^{3}$ David Hopkins, 'Dryden and the Tenth Satire of Juvenal', T\&L, 4 (1996), 31-60 (pp. 46-9).

${ }^{4}$ Higden, A Modern Essay on the Tenth Satyr of Juvenal (London,1687), sig. A4v .

${ }^{5}$ Higden, A Modern Essay on the Thirteenth Satyr of Juvenal (London, 1686), p. 3.
} 
Had the Great Bard thy Properer Numbers view'd,

He wou'd have lay'd his stiff Heroicks by,

And this more Gay, more Airy Path pursu'd,

That so much better leads to Raillery. ${ }^{6}$

Octosyllabic couplets were felt appropriate mainly for comic or parodic poetry, and their use in such contexts in original works like Samuel Butler's mock-heroic Hudibras (1663-78), or slightly later by Jonathan Swift, is well known. Their principal association in classically-based English verse in this era is with the travesty traditions to which Charles Cotton's burlesque-Virgilian Scarronides (1665) and Alexander Radcliffe's Ovid Travestie (1673) belong. These somewhat earlier productions are considerably more rough and ready in versification than Higden's Juvenal, deliberately making their clumsiness part of the subversion of the grandeur of the Aeneid or the sophistication of the Amores.

Henry Higden's known work does not currently extend beyond these three items - verse translations of two of Juvenal's satires, and the (prose) stage play The Wary Widow. But two substantial further classical imitations can now be added to this limited record. I turn first to Higden's version of a Horatian satire, a full text of which appears in print for the first time in the latter part of the present article.

Five extant copies are known to me of this English verse translation of Horace's Satire 1.2 which was apparently composed about 1690 . These copies are found in the following manuscript sources:

${ }^{6}$ Higden, A Modern Essay on the Tenth Satyr of Juvenal (London, 1687), sig. a1 ${ }^{\mathrm{v}}$. 
1. Bodleian Library, MS Rawl. poet. 159

2. Victoria and Albert Museum, Dyce Catalogue no. 43

3. Österreichische Nationalbibliothek, Cod. 14090

4. Nottingham University Library, Portland MS PwV43/3

5. Beinecke Rare Book and Manuscript Library, File 17462

In four of the five copies no ascription is hinted at, but the Beinecke copy carries the following heading, clearly in the hand of the original scribe and not a later addition:

\author{
The Second Satyr \\ of the first Book of Horace \\ made English. \\ By H: H:
}

The initials are not the only feature connecting this work to Higden. This Horatian imitation also employs the octosyllabic couplets he used for his Juvenalian satires, and these octosyllabic couplets are of very much the same character. As we shall see, certain local details also strongly suggest the same hand in both. Why initials only, and why no ascription at all in the other copies? Probably for the same reason that this imitation went unprinted: its content is obscene. ${ }^{7}$ The work was evidently sufficiently attractive to readers for it to be copied and recopied for circulation between acquaintances, or within larger commercially-produced manuscript compilations, ${ }^{8}$ but it may well

\footnotetext{
${ }^{7}$ A secondary reason might be that the imitation names real-life figures in satirical connections, but such names could easily be replaced by rules in print.

${ }^{8}$ Of the five known copies, the Beinecke's began life as an independent manuscript, carrying an ownership inscription ('John Adamson') in the space between the heading and the first line, while
} 
be that Higden would not have wished to acknowledge it publicly. ${ }^{9}$ The Latin satire was itself often omitted or cut short in editions of Horace's works for reasons of its verbal obscenity and its treatment of sexuality; even in the twentieth century, 'coarse' and 'sensational' were just two of the words used to describe this Horatian satire on sexual indulgence and adultery. ${ }^{10}$ In the twentieth century, too, it was still common for editions as well as commentaries and translations to exclude everything in the Latin from line 24 or 28 onwards (it is 134 lines long).

By 1690, the approximate date of Higden's Satire 1.2, several selective attempts at translation and imitation of 'Horace in English' had appeared, and Horace's early modern status as a moralist ensured that the Satires figured among them. Attitudes to Satire 1.2 must have varied, and it was ignored by some of those who translated other parts of the Horatian corpus, but Higden's version was by no means unprecedented. There were two recent predecessors: Alexander Brome in

the Bodleian copy was also once a 'separate', with its own pagination, before being bound into a volume containing many other separates. The rest of the five manuscripts listed (nos 2-4) are the type of 'vast manuscript anthologies' that from the late 1680s onwards represent a 'consolidation of the court satire of the previous two reigns' (Harold Love, English Clandestine Satire, 1660-1702 (Oxford, 2004), p. 64). All come from the so-called Cameron scriptorium (a scriptorium was a concern which carried out copying to order from its stock of poems), with the texts of nos 2 and 3 being almost identical even in very small details.

${ }^{9}$ This is not to suggest that the Beinecke copy or any of the other manuscripts addressed in the present discussion are autograph: there are no indications of this anywhere. Nor does the Beinecke copy necessarily imply that other exemplars had the words 'By $\mathrm{H}: \mathrm{H}:$ ' in their headings: it may be that this copyist had more direct knowledge of the author's identity.

${ }^{10}$ See H. Rushton Fairclough's Loeb edition, Horace: Satires, Epistles, and Ars poetica (1926; revised edn Cambridge, MA, 1929): 'This immature and forbidding sketch, coarse and sensational in tone, and doubtless one of Horace's earliest efforts' (p. 17). 
his Poems of Horace, 1666, and Higden's near-contemporary Thomas Creech in his Odes, Satyrs, and Epistles of Horace, 1684. Presumably both could excuse a translation of 1.2 on the grounds of an obligation to include all the Satires for completeness' sake, but, as we shall see, Brome, in particular, in any case produces a sanitized English 1.2.

These two versions, and a further selection of later English translations of Horace's Satire 1.2, have recently been compared in an essay by Catherine Schlegel. She finds that Brome and Creech reflect 'the liberalism of the post-Restoration period that is much noted by students of that era', and which is not in evidence in eighteenth- or nineteenth-century translations of Horace's Satire 1.2. Creech, she concludes, is 'not without his moralizing', but both he and Brome 'have a natural idiom at their disposal that captures Horace's Latin better than English translations have since'. ${ }^{11}$

Brief comparison of Creech and Brome with Higden's Horace is worthwhile; all three translations possess different qualities. Schlegel compares the earlier English versions of Horace's lines 68-71:

huic si mutonis verbis mala tanta videnti

diceret haec animus: "quid vis tibi? numquid ego a te

magno prognatum deposco consule cunnum

velatumque stola, mea cum conferbuit ira?"12

${ }^{11}$ Catherine Schlegel, 'Horace Satires 1.2: Taste and Translation', CML, 22 (2002), 57-83 (pp. 61 2).

${ }^{12}$ Daniel Hooley's forthright translation runs: 'What if the voice of his cock, as he looked on such calamity, would say to him this: "What do you want? Do I ask you for a cunt descended from venerable consul or posh-gowned when my desire boils up?' '. Daniel Hooley, 'Horace's Rud(e)- 
Schlegel (p. 79) is particularly interested in the words 'mutonis' and 'cunnum'. 'Muto' and 'cunnus' are, as Emily Gow puts it, 'the candid Latin equivalent of four-letter words ... for the sexual organs (or standing for the whole person).${ }^{13}$ Brome glosses over these, rendering the first highly euphemistically as 'Natural genius' and ignoring the second completely:

Now if that Natural genius of his

Should say to him, when he had seen all this,

Sir, what d'you mean? Do I require, when e're

I am inrag'd, the Daughter of a Peer

Or any marri'd woman $?^{14}$

Creech is much more upfront, and verbally obscene:

Suppose his Whore-Pipe now being vext at this,

Should ask him, did I want a Noble Miss,

A Whore of Quality to cool my Flame?

No, I had been content with meaner Game. ${ }^{15}$

In Higden's version this passage is expanded and given a different turn, steering it away from

imentary Muse: Sat. 1.2', ElAnt, 5.2 (October 1999). Quoted from

<https://scholar.lib.vt.edu/ejournals/ElAnt/V5N2/hooley.html>, accessed 29 January 2019.

${ }^{13}$ Horace: Satires, Book I, edited by Emily Gowers (Cambridge, 1981), p. 88.

${ }^{14}$ Alexander Brome, The Poems of Horace (London, 1666), p. 194.

15 Thomas Creech, The Odes, Satyrs, and Epistles of Horace (second edn, London, 1684), p. 378. 
verbal obscenity and improving the comedy. All the translators follow the Latin in assigning words to the penis, but Higden creates a somewhat more fully scripted dramatic exchange; a formal speech, or rather two. As in the other cases, the 'poor sneaking squire' protests to his 'knight' that it was not he who cared about the social standing of the sexual partner:

\section{Pego's Defence}

Say, if you can, did I require

One nobly born to quench Love's Fire?

Or care I, when my Mettle's hot,

What Sire my manag'd Filly got?

The Knight's Answer

To whom the Knight: My Mistress springs

From antient Race of Saxon Kings:

Her Beauty's crown'd with noble Birth;

I scorn the Mushrooms of the Earth.

Higden's slightly more elaborate dialogue goes one step further than Brome or Creech, whose versions allot fewer words to Pego and make the reply much terser. ${ }^{16}$ Higden's dialogue has the scope to suggest two speaking styles, and so to develop hints of character for the speakers. Pego's nimble syntactical inversions and sub-clauses contrast with the simple grammatical constructions used by the 'knight'. It is a momentary double act, and this switch between Pego's rhetorical facility

\footnotetext{
${ }^{16}$ Brome continues rather feebly: 'what could he | Then answer to't? that womans meat for me, | Who is descended of a noble stem'. Creech has 'What answer could be given? what be said? Only, forsooth, She was a Noble Maid'.
} 
and his interlocutor's plain iterative mode hints that Pego is suave, fast-thinking, witty, whereas his owner is ponderous of speech, and fixed of attitude. Tonally, too, Higden keeps things attractively light-touch: the joke name 'Pego' is not a word entirely from the stews, as Creech's 'whore-pipe' must be. Equally, he avoids the wooden literalism of Brome: for Brome's 'when e're | I am inrag'd' (Horace's 'diceret haec animus', 69) he offers 'when my Mettle's hot'.

This, of course, is to judge these three responses to the Horatian satire as English writing, not to assess them in terms of their accuracy as guides to the meaning of the Latin. No doubt Brome and Creech, in their restraint, have much more of that quality traditionally called 'fidelity' towards their source. Overall, one might note, Higden's 313 lines compare to 228 in Brome and 185 in Creech, a disproportion too large to be accounted for solely by his predecessors' use of longer, tensyllable lines. Yet there are plenty of points at which an imitator like Higden can rise to Horace's challenge where a translator, with less freedom, might not. One example must suffice: a moment late in the satire when Horace's speaker expresses his preference for less socially elevated sexual partners. He names two female figures of exalted rank from the story of the earliest era of Roman settlement; his partner, he says, is everything they could be:

haec ubi supposuit dextro corpus mihi laevum, Ilia et Egeria est

(Hooley: 'when such a one has placed herself just so, body to body, she is an Ilia and Egeria together')

Creech omits 'Ilia' but retains the name 'Egeria' at the probable cost of puzzling many readers; his translation does not provide notes (it reads: whil'st She my Arms doth fill, | She's my Egeria, or what e're I will', p. 381). Brome, perhaps for this reason, avoids names altogether, making the 
Horatian speaker's point, as a consequence, much less clear:

When such a Creature in mine Armes does lie,

She is my Love, my Queen, my Deitie

(Brome, p. 197)

At this point Higden rather ingeniously uses two names from English history to correspond to the Roman ones. They are names which had become proverbial and would have been readily recognized by his readers, belonging to two famous mistresses of past kings of England. Jane Shore, the concubine of Edward IV, is frequently named in Shakespeare's Richard III. Rosamond Clifford belongs to the twelfth century; she was the mistress of Henry II, and became the subject of many legends and stories:

Her when I clasp with all her Charms,

I'th' Circle of my willing Arms,

And thus dissolve in Love, 'tis she

Is Shore and Rosamond to me

$(288-91)$

Higden's specificity answers to the Horatian passage, and, like so many other features of this imitation, accommodates it to a new English context.

I now turn to the second verse translation which I believe should henceforth be attributed to Higden. This appears, uniquely to my knowledge, in another, otherwise unconnected, Rawlinson manuscript in the Bodleian Library: MS Rawlinson poetry 195. It was first printed, as an anonymous work, in 
my compilation Newly Recovered English Classical Translations, 1600-1800 (Oxford, 2018; hereafter 'NRECT'). It is an imitation of Juvenal's Sixth Satire (of 661 lines) in English octosyllabic couplets (at a length of 1,457 lines). It appears in NRECT as items JU01 and XJU01, the first being the selections included in the print publication, the second being the complete text of the imitation which appears in the digital Annexe to that publication. ${ }^{17}$

Discussion and illustration of this work (hereafter ' $\mathrm{J} 6$ ') will be confined here to the question of attribution, but this is not an open-and-shut case; various kinds of evidence must be noted. For one thing, English imitations of Juvenal were not so rare in the later decades of the seventeenth century that there is prima facie reason to associate Higden's printed version of Satire 10 with this imitation of Satire $6 .{ }^{18}$ All the same, in 2018 my editorial note to this unassigned Juvenal 6 registered that 'within the wider history of Juvenalian imitation, the closest predecessor is Henry Higden, whose versions of S13 (1686) and S10 (1687) are the only precedents for the use of octosyllabics'. The reason I went no further is given in the next sentence: 'But although their effect is often close to burlesque, Higden's work is positively restrained in comparison with this Satire 6 (NRECT, p. 215).' Thanks to the emergence of Higden's Horace Satire 1.2 (hereafter 'H1.2'), the 'restraint' I had in mind can now be seen to be a feature of only part of his output of imitations of ancient satire. In the offensiveness of their content, both the previously unattributed satires are beyond risqué: they are outrageous.

In both cases, the rare choice of octosyllabic rhyming couplets is enough in itself to create suspicions of a connection with Higden's previously known imitations. Beyond this, it is not only a question of the verse form selected, but of the way it is used. As already noted, Higden's rhymes

\footnotetext{
${ }^{17}$ A free-to-download pdf of the complete Annexe is available at <nrect.gla.ac.uk>.

${ }^{18}$ For Juvenal translations and imitations printed 1660-1700 see my 'A Checklist of Restoration English Translations and Adaptations of Classical Greek and Latin Poetry, 1660-1700', T\&L, 1
} (1992), 52-67 (pp. 59-60). 
are generally not clumsy. They might perhaps be called 'awkward', but this is deliberate. It is made part of the fun that the reader often registers them as deliberately cheeky or contrived:

'broker/bespoke her' (J6, 1317-18), 'Madams/Jack Adams' (J13, p. 25), 'Bon 'Sperance/Elephants' (J10, p. 25), 'should say't/Magistrate' (H1.2, 69-70). Another very pronounced characteristic is syntactical inversion: 'And should I strive of each disease | To give the names and qualities' (J10, p. 39); 'With Joy the Triumph bear away' (H1.2, 249); 'If her spouse to the wars is sent' (J6, 1282). This might be supposed a natural result of the pressures created by the joint demands of rhyme and the short eight-syllable line, but in fact it is notably rare in both Cotton's Scarronides and Radcliffe's Ovid Travestie, whereas it is pervasive in all four of the Juvenalian and Horatian imitations under consideration here.

Aside from the verse texture there is the matter of our author's pronounced interest in the contemporary theatre. The author of J6 is, I wrote in 2018, 'very familiar with the contemporary London stage, though he does not sound like an insider' (NRECT, p. 215). Until the appearance of his one work for the stage in 1693, Higden, as far as we know, was not professionally associated with the theatre, but a keen interest is reflected in his allusions to stage plays currently or recently in the repertoire such as Wycherley's The Country Wife of 1675 (J6, 120). That interest seems to combine at one point in J6 with close knowledge of a legal man's way of life of when he writes of the summertime closure of the London theatres:

Others, while the dead Long Vacation

Causes from stage-playing a cessation -

While, in the empty theatre,

The hollow claps of doors you hear,

Sadly the tedious weeks they pass

From Trinity to Michaelmas.

(J6, 180-5) 
In the English legal calendar, Trinity Term still ends in July, and Michaelmas Term begins in October. In the Horatian satire the allusions to the contemporary stage are present once again, and some are even more up-to-the-minute. The satirist imagines lovers who are caught with other men's wives and violently castrated; they are 'Poor Pisquils'. Pisquil was the name of a eunuch in Sir Charles Sedley's stage comedy Bellamira, 1687.

The interest in the stage is linked to the two most specific connections I have so far noted between the Juvenalian and the Horatian satires I now wish to attribute to Higden. In these cases the imitations use names which, originating in stage plays, had passed into common currency as typenames. In the Juvenal, the speaker at one point addresses a friend, in dissuasion from marriage:

Yet thou, incorrigible Tony,

Design'st, in this age, Matrimony;

And, more thy mistress to enamour, Art rigg'd by quaint valet de chamber.

$(\mathrm{J} 6,60-3)$

A 'Tony' was a fool or ninny, and the term appears to have its origin in Middleton's The Changeling (1623, but known to have been performed as late as 1668). In the second scene two characters resolve to abbreviate the name of another, Antonio: 'Tony, Tony, 'tis enough, and a very good name for a fool', affirms Lollio. OED records 'Tony' as a term of abuse from 1654 until the later eighteenth century. But it is not, perhaps, one we would expect to encounter much in verse contexts, so its reappearance in the Horatian satire may be significant:

All men point at him for a Tony, That runs out a fair Patrimony, 
Whether for sake of Miss, or Spouse,

That fond Plea no wise Man allows.

(H1.2, 137-40)

More decisive, because still more unusual, is the recurrence of a second stage-related insult or joke name across these two productions. Sir Jeffrey Smellsmock is a comic character in Thomas Shadwell's play The Miser (1672). The word 'smellsmock' is thereafter used allusively, and generically, in Sedley's The Mulberry-Garden (1675) and Edward Ravenscroft's The English Lawyer (1678), becoming a term for 'a licentious man', as the dictionary records. But, while no doubt a modish enough term in the speech of this era, it remained extremely rare in literary contexts, and had never appeared in verse at all by $1690 .{ }^{19}$ It looks more than a coincidence, therefore, that it appears both in the Horatian and Juvenalian satires:

What makes Sir Smellsmock, that rank goat,

On his fair, buxom wife to doat? $(\mathrm{J} 6,373-4)$

As did Sir Smell-Smock ${ }^{20}$

Who, real Passion to discover,

Gave up into his Mistress' hands

\footnotetext{
${ }^{19}$ Other than the works just noted, ECCO musters only six appearances of the term in print between 1672 and 1690. Two of these are in dictionaries, and only one has a literary context, in John Philips' 1687 translation of Cervantes’ Don Quixote.

${ }^{20}$ Uniquely in the Juvenal 6 translation, this is a metrically defective line, perhaps reflecting the translator's slightly impetuous keenness to use the term.
} 
His old paternal Seat of Lands:

$(\mathrm{H} 1.2,121)$

University of Glasgow

\section{Horace's Satire 1.2 Imitated by Henry Higden}

The text which follows is based on the Bodleian manuscript copy, no. 1 in the list given on p. 000 above, with a handful of corrections absorbed from others. Given that three of the five known manuscripts of this imitation (nos 2-4) were produced by the same commercial scriptorium, it is not to be expected that they will diverge significantly from each other, and my checks and spot-checks among the exemplars have revealed very few variants of substantive importance.

The intention has not been to provide a diplomatic transcription, but a reading text. The general principles on which the manuscript text has been edited are those developed for NRECT; the principles are set out on pp. 8-11 of that work. In this case the copyist took some pains to create a complete and consistent text, and editorial intervention has not been heavy. Three of the notes are signalled in my text as appearing in manuscript, and may well be originally the translator's own, as opposed to a copyist's.

Hor. Lib. i.

The Second Satyr.

Bauds, Fiddlers, Whores, Buffoons ${ }^{1}$ o' th' Age,

\footnotetext{
${ }^{1}$ Bauds ... Buffoons] 'Bawd' and 'whore' are terms which could, in the later seventeenth century, be applied to males as well as females, but more often refer to the latter. Fiddlers: those who play the instrument for hire. Buffoons: those 'whose profession is to make sport by low jests and antick postures' (Johnson).
} 
With the kind Damsels of the Stage,

Quacks, Drolls, Cheats, Bullies, ${ }^{1}$ Spendthrifts, all

Condole Lord Squander's ${ }^{2}$ Funeral:

Because he bore a Noble Mind,

And always Liberal was, and kind.

$<1$ line \#>

This wealthy Wretch still dreads to lend,

Or serve a worthy wanting Friend,

Lest the Censorious World should call

Him Cully, ${ }^{3}$ or a Prodigal:

Ask t'other Coxcomb, Why such haste

To lay his Grandsire's Manners waste?

Why in vain Treats, Expense, and Play,

He foolishly throws all away?

He cries: "What some praise, others blame;

What's one Man's Pride,'s, another's Shame:

${ }^{1}$ Quacks ... Bullies] A quack is a charlatan of any kind, a suitable description of Horace's 'pharmacopolae' (1), not only sellers of potions but confidence tricksters. A droll is a jester or wag; a bully is a blustering 'gallant', especially 'one who lives by protecting prostitutes' (OED).

${ }^{2}$ Lord Squander's] The dead man in the Horatian satire is a real individual, whereas this is a type name or joke name. There is a mixture of both kinds of name in each text, however; for an example of a real-life name in the imitation, see the final line.

${ }^{3}$ Cully] 'Simpleton'. 
Weigh'd in false Scales of partial Reason,

What's one Man's Meat,'s another's Poison."

Rich sordid Gripe ${ }^{1}$ hoards his Estate,

To be secur'd from Bash 's ${ }^{2}$ Fate;

Tho' rich in Land and Cash, the Knave

Extorted Proc \& $\mathrm{Con}^{3}$ will have,

Where heedless Fop's extravagancies

Run high, his Usury inhances:

The nearer still the Spark's to Ruin,

He spurs him on to his Undoing.

From Tradesmen's Books he culls with Care

The Name of every worldly Heir;

Draws into Statute, Bond, and Warrant,

The clutchfist Miser's Heir apparent:

Whose craving, hungry Appetite

Makes him at Stystead-Bargains ${ }^{4}$ bite.

${ }^{1}$ Gripe] Slang for 'usurer' (OED 6b).

${ }^{2}$ Bash's] 'Bash' seems to have been a stock name for one who is cheated or imposed upon.

Compare Scroope's In Defence of Satyr, line 77: 'Simius, the Buffoon, or Cully Bash' (a cully is 'a dupe, gull', $O E D)$.

${ }^{3}$ Proc \& Con] Procuration \& Continuation, which Usurers exact from their needy Clients (ms note). 'Procuration' is a fee for negotiating a loan, 'continuation' one for extending it.

${ }^{4}$ Stystead-Bargains] This term seems not to be found in printed sources of the period, but evidently refers to exploitative financial arrangements. Stisted is a parish in Essex, forty miles north-east of London. 
The words of some one, pleading

in Excuse of the Usurer

Why should he not o'rereach, and cheat,

Since Heav'n still favours his Deceit?

You see, he lives at a good Rate,

And shapes Expense to his Estate.

The Author's Reply

But who believes your Speech, who sees

He wants even Necessities?

Th' unhappy Father (whom we see

Afflict himself in Comedy, ${ }^{1}$

Because his wild rebellious Son

O'erseas is to the Indies run)

Lives not in such a wretched state,

Or suffers Penance at his Rate.

If any one desires to know

From whence these diff'ring Humours flow:

The Reason's plain: when Fools would shun

One Vice, on th' opposite they run;

Who fear a Shelf, and steer too wide,

Oft shipwreck on the other side,

Knowing no mean 'twixt th' extreme Vices

\footnotetext{
${ }^{1}$ Father ... Comedy] Horace (line 20) refers to a character in Terence who lives in misery after banishing his son.
} 
Of nauseous Slovens, and Sir Nices, ${ }^{1}$

Who Noke's broad wheel-brims deride,

Cock up their own scarce Halfcrown wide:

If penthouse Hat move with excess,

Too narrow's Comical no less. ${ }^{2}$

His strong Pulvilio's overcome

With Polecat scents that choke the room: ${ }^{3}$

The middle Course most decent seems;

But Folly will be in th' Extremes.

$<1$ line \#>

Some, of humorous Appetite,

In none but Quality delight;

While other jolly Lovers choose

The rankest Game in all the Stews.

A certain ancient Virtuoso,

Having but pleas'd his Mistress so so,

March'd out, and with good Manners bowing,

Cried, "Gentlemen, God speed your ploughing":

${ }^{1}$ Sir Nices] Sir Courtly Nice, the most popular of John Crowne's comedies, reached the stage in 1685 and was printed the same year.

${ }^{2}$ Who Noke's ... no less] Some of this vocabulary of hat brim styles has escaped the historical record, but the general sense of 'no happy medium', the overall theme, or ostensible overall theme, of Horace's satire, is evident. Move: to laughter.

${ }^{3}$ Pulvilio's ... room] Pulvilio was a fragrant powder sprinkled on the hands or on a wig. In Horace, while one man 'smells of perfume', another 'smells as strong as a goat'. 
And would you think Cato should say't,

That was a sober Magistrate?

When Youths than rutting Deer grow madder,

With Tool, swell'd up with Lust, like Bladder,

'Tis fit for Ease he hither come,

And have a Run at gamesome Bum:

While guilty Knaves employ their Lives

To cony-catch ${ }^{1}$ their Neighbours' Wives,

When they, at every public Mill,

Without a crime, ${ }^{2}$ may grind their fill.

"Such common Game (says one) I scorn,

I only noble heads would horn."

Observe what risks, and dang'rous Measures

They tread, forsake the Road to Pleasures?

When their fantastic love engages

To trespass, and break others' Hedges,

What various sorts of Hazards use

T'attend them hunt in strange Purlieus?

What wild Frays to Disasters fright

And dog 'em, in stoln Flesh delight?

\footnotetext{
${ }^{1}$ cony-catch] To coney-catch is to cheat or deceive, but, noting that this does not make full sense, we realize that a pun is intended (see $O E D$, 'cunny').

${ }^{2}$ without a crime] To their neighbour (ms note).
} 
Who, after all their Toil and Court, ${ }^{1}$

Seldom enjoy the wish'd-for Sport.

This, from a high exalted Story

Vaults, to escape his Cuckold's Fury;

T'other, surpris'd in a strange Bed,

Is by remorseless Hands whipt dead;

While this, discover'd, flies the City,

He's stript and plundred by Banditi;

Th' other had been a Gelding made

If he had not dear Ransom paid;

Others, trepann'd ${ }^{2}$ by cruel Foes,

Have Balls and lecherous Tail dock'd close.

No Fair Judge at that act will rail,

But who in's youth has lost his Tail;

Poor Pisquils ${ }^{3}$ then, scorn'd by the Wives,

Are Drone-like driven from their Hives.

'Tis safer Trade for Toys and Kisses,

In Commerce with professèd Misses; ${ }^{4}$

With whom the Fool no better thrives

Than he who poaches after Wives.

${ }^{1}$ Court] $O E D$ n. ${ }^{1}, \mathrm{~V}$ : 'homage, favour', citing Dryden, 1676: 'Flatter me, make thy Court, and say, it did.'

2 trepann'd] 'Entrapped', 'ensnared'.

${ }^{3}$ Pisquils] Pisquil is a eunuch in Sir Charles Sedley's stage comedy Bellamira, 1687.

${ }^{4}$ professèd Misses] MS 'professed'; Misses: prostitutes. 
For her who's purchas'd for a Guinea,

Who bleeds a sum ${ }^{1}$ is deem'd a Ninny;

While he's reputed $\operatorname{stanch}^{2}$ and wise

That frankly pays a Market-price:

Him Misses love, respect, and call

Free, gallant, just, and liberal,

That will not strain his Purse and Means

To humour wheedling, jilting Queans. ${ }^{3}$

Some Fops are ravish'd with delight,

Boast and insult in their Conceit,

That they with Matrons hold no League,

Nor drive with Wives no close Intrigue;

As did Sir Smell-Smock ${ }^{4}$

Who, real Passion to discover,

Gave up into his Mistress' hands

His old paternal Seat of Lands:

Thank Heav'n, they never so miscarry'd,

Or doted on a Jilt that's marry'd.

The Author's Answer

\footnotetext{
${ }^{1}$ bleeds ... sum] Compare $O E D$, 'bleed' v. 5: 'to pay through the nose for'.

${ }^{2}$ stanch] '=staunch'; see OED 2 quot.: 'the blood continued staunch' (i.e. 'not flowing out').

${ }^{3}$ Queans] A quean was 'a bold or impudent woman; a hussy; a prostitute' (OED 1).

${ }^{4}$ Sir Smell-Smock] Sir Jeffrey Smellsmock is a comic character name in Thomas Shadwell's play The Miser (1672). A 'smell-smock' is 'a licentious man' (OED). This metrically defective, unrhymed line is the only example in this composition.
} 
But on the Stage, or common Whore

To dote, may wound your Fame; and more

Your Purse, and Fortune. Ruin's the same,

Wrought by a Miss, or Marry'd Dame;

To scape one Rock you must not boast,

When you are on another lost;

Who safely steers, where others hit,

Proclaims his Conduct, and his Wit:

The Consequence will prove the same

Where e're you shipwreck your good Name;

All men point at him for a Tony, ${ }^{1}$

That runs out a fair Patrimony,

Whether for sake of Miss, or Spouse,

That fond Plea no wise Man allows.

$<1$ line \#>

Poor Peacock was expos'd to Laughter,

Trapt in Design on a Lord's Daughter;

With Fist and Cudgel laid on thick,

Then with Cold-iron they hash'd him quick:

But that which most did aggravate

Malicious Rigour of his Fate:

The Jilt for whom he was a Martyr,

His Rival in her Arms did quarter.

Peacock, being narrowly escap'd,

\footnotetext{
${ }^{1}$ Tony] 'Fool', 'ninny'.
} 
throws the whole blame of his

Misadventure on poor Pego; who,

in a pretty Prosopopaia, Argues

the Case.

The Knight, escap'd so as by Fire,

Blames Pego, his poor sneaking Squire,

As if he, Serpent-like, was Tempter,

And egg'd him on to this Adventure,

Tho' he, poor Snake, shar'd the Disaster,

And was drawn in by his lewd Master.

His Innocence he justify'd,

And thus to his Knight's Charge reply'd.

Pego's Defence

Say, if you can, did I require

One nobly born to quench Love's Fire?

Or care I, when my Mettle's hot,

What Sire my manag'd Filly ${ }^{1}$ got?

The Knight's Answer

To whom the Knight: My Mistress springs

From antient Race of Saxon Kings:

Her Beauty's crown'd with noble Birth;

I scorn the Mushrooms of the Earth.

The Author's words

\footnotetext{
${ }^{1}$ manag'd Filly] In horse riding, a 'managed' animal was one which had been put through the exercises of the manège - the movements in which a horse was trained.
} 
Wise Nature does instruct us, Sir,

What is most fitting we prefer;

And to avoid what's hurtful teaches:

Nature's the inward Light that preaches.

We rather should let Love miscarry,

Than rob Life of what's necessary: $\quad 170$

'Tis better curb a headstrong Freak, ${ }^{1}$

Than give the Reins, and break our Neck.

Of Quality leave vain Pursuit;

That Game still brings more Pain, than Fruit:

Nay, when we hope to get our full, ${ }^{2}$

We find it true, more cry than Wool. ${ }^{3}$

Nor can rich Dress, or Jewels bright,

Make Legs or Thighs more straight or white;

And Courtesans can often show

The fairest Prospect of the two:

They honestly expose their Ware,

To open View, naked and bare;

Nor practice shuffling ${ }^{4}$ Tradesmen's Slight,

To put off coarse Ware by false Light,

Contrive not to deceive your View;

${ }^{1}$ Freak] 'A capricious humour' $(O E D)$.

${ }^{2}$ full] 'Fill' (a standard usage).

${ }^{3}$ more ... Wool] 'Great cry and little wool' is a proverbial dismissal of those who promise more than they deliver.

${ }^{4}$ shuffling] 'Deceiving'. 
Here you may see, and handle too.

Where noblest Jockeys Horses buy,

Each part's survey'd with curious Eye,

Lest, by some handsome Shape betray'd,

They dote upon a founder' $\mathrm{d}^{1} \mathrm{Jade}$;

Peruse each Limb with Care and Heed,

Judge if he's made for Strength or Speed;

Observe his Buttocks fair and clean,

His rising Neck, Head small and lean,

Wide Nostrils, Eyes quick rowling bright;

Such Royal Chapmen² are i'th' right.

False Horscoursers, ${ }^{3}$ like Bands ${ }^{4}$ untrue,

Avoid a Trial, or fair View;

Teaching their Rascal Deer to fly

To Covert, from a Woodman's Eye;

And boldly, to the Bubble's ${ }^{5}$ Face,

Commend those Shapes deserve disgrace:

Praise lean Arms, bandy Legs, and to't

A crooked, nasty, pasty Foot;

A stout thick Waist, which does arise

${ }^{1}$ founder'd] 'Lamed'.

${ }^{2}$ Chapmen] 'Merchants', 'dealers'.

${ }^{3}$ Horscoursers] 'Dealers in horses' (Johnson).

${ }^{4}$ Bands] 'Promises'.

${ }^{5}$ Bubble's] 'Dupe's' (OED 3). 
From her pinch'd Buttocks, and lank Thighs;

Value consumptive ${ }^{1}$ Ware, upon

Limbs meagre, like a Skeleton.

No Shapes but of the Face you see

In Wives of Noble Quality,

Unless, like Harvey, ${ }^{2}$ she will wear

Short Coats, to make her Legs appear.

If you in Conquering Wives take pride,

They, like strong Towns, are fortify'd;

Where you will find their guarded Breech

Surrounded with a Wall and Ditch;

With Veil and Farthingale, design'd,

Like warlike Curtain, for a Blind ${ }^{3}$

Avenues block'd with Coach and Chair,

Spy Sentinels plac'd every where,

Tire-women, Lackeys, Valets, Pages,

With humble Friend, flatters for Wages;

With Engines, Machines, Stratagems,

Which this strong Fortress strangely hems:

Ne'er think to starve her; she'll withstand

${ }^{1}$ consumptive] 'Wasted'.

${ }^{2}$ Harvey] Not, at this date, Pope's Lord Hervey, but perhaps his father John Hervey, first Earl of Bristol (1665-1751).

${ }^{3}$ Like ... Blind] 'Like the wall of a fortified place, as a means of concealment.' 
An Ostend seige, ${ }^{1}$ that's so well mann'd.

Th' other, like open village lies,

Where nothing baulks your Hands and Eyes:

Perhaps she breathes a sweeter Air, )

All thro’ transparent Gauze, as clear, ） $\quad 230$

And colour of the skin and Hair; )

Straight Legs and Thighs, a pretty Foot,

With charming Spot (blind Cupid's Butt). ${ }^{2}$

'Tis strange he hits so small a Mark,

But Instinct guides Love in the Dark:

Her upright Body, slender Waist,

That's with a circling Span embrac'd.

Would you not rather choose plain Dealing,

That bars neither your Sight nor Feeling,

Rather than pay a wheedling Cheat

Beforehand, for blown, ${ }^{3}$ tainted Meat?

The Argument of the Courter

of Wives of Quality

'Tis true; but my fantastic Love

Still nice and humorsome does prove;

${ }^{1}$ Ostend seige] The Siege of Ostend, 1601-4, was notorious for its length. English troops helped defend the city.

${ }^{2}$ Spot ... Butt] Cupid's 'butt' or target ('Mark', 234) is a cosmetic beauty spot fashionably worn on the face.

${ }^{3}$ blown] 'Stale, flat, that has lost its freshness' $\left(O E D\right.$, adj. $\left.{ }^{1}, 2\right)$. 
When once possess'd, I loath the Game,

And always court the flying Dame.

Like a keen Huntsman, I with Hounds

Run the Hare briskly o'er the Downs;

And, having fairly kill'd the Prey,

With Joy the Triumph bear away.

This Dish my Board doth proudly grace,

And pleases, like the boasted Chase;

But if I meet a shot-cours' $\mathrm{d}^{1}$ Hare,

Or basely strangled in a Snare,

A Jew will sooner Swine's flesh eat,

Than I can swallow such loath'd Meat.

The Author's Words

Think you, this Fancy will assuage

Your Grief, or cure Love's burning Rage?

Wise Nature would confine our roving

Cupids, and set bounds for Loving;

Forbids us hunt chimeric Fancies,

Like crack-brain'd Heroes in Romances:

And, full as wise as that Intriguer,

Will Towns impregnable beleaguer.

If't happen, thro' excess of Drowth,

Your burning Tongue cleave to your Mouth;

\footnotetext{
${ }^{1}$ shot-cours' $d$ ] Evidently meaning 'already shot' and dressed, as in Horace, but the term seems to be unrecorded.
} 
Will you insist they'll bring you first

Your gold Cup, ere you quench your Thirst?

Or, pinch'd with Hunger, will you starve

Unless they Quails or Lampreys serve?

In case of need, will you refuse

The Mistress or the Maid to use,

Who luckily are plac'd at hand,

And ready to obey Command?

Will you, when help's at hand, let Lust

Rage, till your swelling Engine's burst?

Thank Heav'n, I'm not of that nice Mind;

I'm for a Love easy and kind:

The noisy Coquettes I detest,

And love her thinks few words are best;

Who only says (granting your Suit)

"Money" anon, when he's gone out.

Turner and Fox, ${ }^{1}$ that hister ${ }^{2}$-like

Who on the easiest Terms will strike:

And, when you beckon, does not linger,

But's ready when you wag your Finger.

Let her be straight, clean, handsome, tall,

No fairer than is natural;

Her when I clasp with all her Charms,

\footnotetext{
${ }^{1}$ Turner and Fox] Unexplained.

${ }^{2}$ hister] Cant for a Wench (ms note).
} 
I'th' Circle of my willing Arms,

And thus dissolve in Love, 'tis she

Is Shore and Rosamond ${ }^{1}$ to me:

In that transporting hour, with ease

I'll give her what Court-name ${ }^{2}$ I please.

Here I can frolic, without dread

Of a Surprise, tho' in her Bed;

Nor fear her jealous Spouse will come,

Recall'd by Spies, at Midnight home.

The Gates are broke, the House beset,

And Instruments of Ruin met;

The Lady starts pale from her Bed,

Her guilty Confident's half dead:

The Baud a Cart or Pillory fears, ${ }^{3}$

Forebodes the Whip, or loss of Ears;

${ }^{1}$ Shore and Rosamond] Jane Shore was a famous royal mistress, the concubine of Edward IV. She is frequently named in Shakespeare's Richard III, but Nicholas Rowe's play The Tragedy of Jane Shore did not appear until some years after the apparent date of this reference, in 1714. Rosamond Clifford belongs to the twelfth century: she was the mistress of Henry II, and became the subject of many legends and stories.

${ }^{2}$ Court-name] Apparently meaning 'courting name', 'pet name'.

${ }^{3}$ Her guilty ... Pillory fears] Both 'Confident' (so spelled by Pepys) and 'Baud' refer to the maid, who has acted as a go-between. A cart was still for Johnson in his 1755 Dictionary a vehicle in which a malefactor is 'exposed ... by way of punishment'. 
The Wife, to save her Life, would scour, ${ }^{1}$

With loss of Jointure and of Dower;

Undress'd and barefoot, Fear persuades

My flight, t'escape from Whips to Blades,

Lest Ransom high my Purse defray,

Or Buttocks dearer Reck'ning pay;

Or, to undo my Reputation,

The Jest is spread quite o'er the Nation:

Such a Surprise the worst Chance is,

Smirk Darnel $^{2}$ be my Judge in this.

${ }^{1}$ scour] 'Run away hastily' a slang word (OED, v. $\left.{ }^{1}, 1 \mathrm{c}\right)$.

${ }^{2}$ Smirk Darnel] The name (sometimes appearing as 'Darnell' in the known manuscript copies) does not occur in printed sources of the relevant period. Higden seems to refer to a contemporary who has suffered a similar 'surprise', which is in line with standard contemporary readings of the Latin. See The Satires, Epistles, and Art of Poetry of Horace (London, 1743), p. 39 (on Horace's line 134): 'The Poet ends with one of the sharpest Strokes of Satire: For this Fabius was a famous Lawyer in those Times, and, being catch'd in Adultery, narrowly escap'd. 